(c) Group of authors, 2019

UDC 616.341:575.191

DOI - https://doi.org/10.14300/mnnc.2019.14124

ISSN - 2073-8137

\title{
GENETIC CHARACTERISTICS OF CHILDREN WITH CELIAC DISEASE LIVING IN THE SOUTH OF RUSSIA
}

\author{
Klimov L. Ya. 1, Stoyan M. V. 1, 2, Kuryaninova V. A. 1, 2, Zakharova I. N. ${ }^{3}$,
} Atanesyan R. A. ', Zavyalova E. V. 1, 4, Kochneva L. D. ', Ivanova A. V. ${ }^{1}$

${ }^{1}$ Stavropol State Medical University, Russian Federation

2 Stavropol Children Clinical Hospital by named G. K. Filippsky, Russian Federation

${ }^{3}$ Russian Medical Academy Postgraduate Continuing Studa, Moscow, Russian Federation

${ }^{4}$ Stavropol Region Clinical Diagnostic Center, Russian Federation

\section{ГЕНЕТИЧЕСКАЯ ХАРАКТЕРИСТИКА АЕТЕЙ С ЦЕАИАКИЕЙ, ПРОЖИВАЮЩИХ НА ЮГЕ РОССИИ}
А. Я. КАимов ${ }^{1}$, М. В. Стоян ${ }^{1,2}$, в.
В. А. Курьянинова ${ }^{1,2}$,
И. Н. 3axapoвa ${ }^{3}$,

Р. А. Атанесян ${ }^{1}$, Е. В. Завьялова ${ }^{1,4}, \Lambda^{4}$. А. Кочнева ${ }^{1}$, А. В. Иванова ${ }^{1}$

${ }^{1}$ Ставропольский госуаарственный меАицинский университет, Российская ФеАерация

2 ГороАская Аетская кАиническая больница им. Г. К. ФиАиппского, Ставрополь, Российская ФеАерация

3 Российская меАицинская акалемия непрерывного профессионального образования, Москва, Российская Фелерация

${ }^{4}$ Ставропольский краевой кАинический консультативно-Аиагностический центр, Российская Фелерация

HLA-typing was performed on 110 children with celiac disease living in the South of Russia to identify HLA-DQ haplotypes. The diagnosis of celiac disease was established for all children following the criteria ESPGHAN 1999 and 2012. There were $50(45.5 \%)$ boys and $60(54.5 \%)$ girls. HLA-positive patients accounted for $108(98.2 \%)$ cases. The most common allele was DQ2 - $87(79.1 \%)$ children, DQ8 - 16 (14.6\%) people, and DQ7 - 5 (4.5\%) patients. DQ2 represented the DQ2.5 allele, 5 in $26(29.9 \%)$, a combination of DQ2.5 with DQ2.2 in $21(24.1 \%)$, only DQ2.2 in 7 (8.1\%) patients. The combination of DQ2 with DQ7 had $25(28.7 \%)$ children and $8(9.2 \%)$ children - the combination of DQ2 with DQ8. The DQ8 allele in $5(31.3 \%)$ was in combination DQ8 with DQ7.

Thereby, the clinical symptoms of the disease did not differ significantly from the type of allele. The highest titer characterized specific autoantibodies (anti-TTG, EMA) in children with the DQ2 allele.

Keywords: celiac disease, children, HLA-haplotype, HLA-DQ2, HLA-DQ8, HLA-DQ7, degree of atrophy by Marsh

Проведено HLA-типирование 110 детям с целиакией, проживающим на Юге России, с целью выявления гаплотипов HLA-DQ. Диагноз целиакии был установлен для всех детей в соответствии с критериями ESPGHAN $1999,2012$. Было 50 (45,5 \%) мальчиков и 60 (54,5 \%) девочек. HLA-позитивные пациенты составили 108 (98,2 \%) случаев. Наиболее часто встречающимся аллелем был DQ2 - 87 (79,1 \%) детей, DQ8 - 16 (14,6 \%) человек и DQ7 - 5 (4,5 \%) пациентов. Аллель DQ2 был представлен DQ2,2 - у 26 (29,9\%), комбинация DQ2,5 с DQ2,2 - у 21 (24,1\%), только DQ2,2 - у $7(8,1 \%)$ пациентов. Комбинацию DQ2 c DQ7 имели $25(28,7$ \%) детей и $8(9,2 \%)$ детей - комбинацию DQ2 c DQ8. Аллель DQ8 в $5(31,3$ \%) случаях был в комбинации DQ8 с DQ7.

Таким образом, клиническая симптоматика целиакии существенно не отличалась от вида аллели. Специфические аутоантитела (анти-ТTГ, ЭМА) у детей с аллелем DQ2 характеризовались максимально высоким титром.

Ключевые слова: целиакия, дети, HLA-типирование, гаплотипы HLA, HLA-DQ2, HLA-DQ8, HLA-DQ7, степень атрофии Marsh

For citation: Klimov L. Ya., Stoyan M. V., Kuryaninova V. A., Zakharova I. N., Atanesyan R. A., Zavyalova E. V., Kochneva L. D., Ivanova A. V. GENETIC CHARACTERISTICS OF CHILDREN WITH CELIAC DISEASE LIVING IN THE SOUTH OF RUSSIA. Medical News of North Caucasus. 2019;14(3):503-507. DOI - https://doi.org/10.14300/mnnc.2019.14124

Для цитирования: Климов Л. Я., Стоян М. В., Курьянинова В. А., Захарова И. Н., Атанесян Р. А., Завьялова Е. В., Кочнева Л. Д., Иванова А. В. ГЕНЕТИЧЕСКАЯ ХАРАКТЕРИСТИКА ДЕТЕЙ С ЦЕЛИАКИЕЙ, ПРОЖИВАЮЩИХ НА ЮГЕ РОССИИ. Медицинский вестник Северного Кавказа. 2019;14(3):503-507.

DOI - https://doi.org/10.14300/mnnc.2019.14124 
anti-DGP - antibodies to deamidated gliadin peptides

anti-TTG - antibodies to tissue transglutaminase

EMA - endomysial antibodies
ESPGHAN - European Society for Pediatric Gastroenterology,
Hepatology and Nutrition

HLA
0 ver the past quarter-century, the incidence of autoimmune diseases, including celiac disease (celiac enteropathy), has been progressively increasing throughout the world [1, $2,3]$. Celiac disease is a systemic autoimmune disease, development of which requires the presence of HLA-DQ2/HLA-DQ8 haplotypes, involvement of autoantibodies - antibodies to tissue transglutaminase (anti-TTG), antibodies to endomysium (EMA), to deamidated gliadin peptides (anti-DGP) as well as an external trigger - gluten [1].

The most important genetic factor predisposing to the development of celiac disease is the presence of HLA-DQ2/DQ8 haplotypes, which are products of class II genes of the main histocompatibility complex (HLA system) $[4,5]$. Genes of the HLA system of class II, which, by modern views, are an integral component of the pathogenesis of the disease, are located at the $6 \mathrm{p} 21.3$ locus of the short arm of chromosome VI. HLA genes are the main genes of celiac disease, whose contribution to the hereditary predisposition is about $40 \%$ and without which the development of celiac disease seems unlikely [6]. The role of these genes is to bind exogenous immunodominant peptides and present them to T-lymphocytes, followed by selective activation and development of a pathological immune response [7, 8].

Numerous genetic studies in patients with celiac disease have shown that the HLA-DQ2 molecule (DQA $1{ }^{*} 0201-\mathrm{DQB} 1{ }^{*} 0201$ и $\mathrm{DQA} 1{ }^{*} 0501-\mathrm{DQB} 1{ }^{*} 0201$ ) occurs in $90-95 \%$ of cases and only in 5-10\% - the HLA-DQ8 molecule (DQA $\left.1{ }^{\star} 0301-\mathrm{DQB} 1{ }^{\star} 0302\right)$ [6, 9, 10]. These HLA molecules can be encoded in cis or trans forms. Homozygotes with the HLA-DQ2.5 haplotype have the highest genetic risk, due to the high affinity for gluten protein binding. The HLA-DQ2.2 molecule has a lower effect on the risk of the celiac disease since it has a different amino acid (phenylalanine instead of tyrosine), which leads to a decrease in binding stability [11]. The risk of celiac disease is higher in individuals homozygous for HLA-DQ2.5 or HLA-DQ2.5/DQ2.2 vs. homozygous for HLA-DQ2.2 or heterozygous for HLA-DQ2.5 or DQ2.2 [6, $12,13]$.

It is now generally accepted that HLA-DQ2/HLA-DQ8 genes in the general population are found in $30-40 \%$ of healthy individuals and only 1-2 \% of HLA-compatible people develop celiac disease $[14,15]$. HLA typing has an extremely high ( $>99 \%$ ) negative predictive value. This is useful for analyzing patients with an ambiguous diagnosis (e.g., enteropathy with seronegative anti-TTG) or those already on a gluten-free diet. Genetic analysis can be used to rule out celiac disease and need for further testing in high-risk individuals due to family history. 60$70 \%$ of the world's population without a genetic predisposition will never be affected by celiac disease. On the other hand, it is still not clear why, with a relatively high prevalence of predisposition alleles, only one out of every thirty of them manifests a disease $[16,17]$.

HLA class II genes are a necessary but insufficient factor for the development of the celiac disease. Studies of genomic associations have revealed other non-HLA genes (more than 40 loci) involved in the pathogenesis of celiac disease $[18,19]$. However, individually, each of these non-HLA genes plays a relatively small role in the risk of developing celiac disease, but together these nonHLA genes are significant [20].
The recommendations of the European Society of Pediatric Gastroenterologists, Hepatologists and Nutritionists (ESPGHAN) allow diagnosis of celiac disease without jejunum biopsy in children with enteropathy symptoms, 10-fold or more anti-TSH IgA levels of the normal upper range, confirmed by the detection of EMA and positive HLA-DQ2/DQ8 haplotypes [21, 22, 23].

The presence/absence of HLA-DQ2/DQ8 system haplotypes is considered as the most important diagnostic and prognostic criterion [24, 25, 26]. The lack of HLADQ2 / DQ8 alleles with high probability indicates a slight risk of developing celiac disease [27, 28]

Over the course of two decades, in the Stavropol Region, on the background of improved diagnostics and the introduction of HLA typing, a marked increase in the frequency of celiac disease in the pediatric population has been noted, reflecting a global trend [29].

The study objective was to analyze the frequency and structure of HLA-DQ haplotypes in children with the celiac disease living in southern Russia and their possible relationship with the characteristics of the clinical, medical history, and morphological picture of the disease.

Material and Methods. The study enrolled 110 children living in the Stavropol and North Caucasus regions, who were examined and treated in the gastroenterological department of the Pediatric Hospital named after G. K. Philippskiy of Stavropol in 2010-2019.

The age of patients was from 8 months to 17 years, of which there were 60 (54.5\%) girls and 50 (45.5\%) boys (average diagnosis age $4.9 \pm 0.4$ years).

The diagnosis of celiac disease is based on clinical, serological (positive anti-TTG, anti-DGP, EMA of IgA and IgG classes), morphological (stages of atrophy 3A-3C following the classification of Marsh-Oberhuber), and genetic (HLA-DQ2/DQ8 haplotypes) ESPGHAN criteria (1990, 2012).

A typical form of celiac disease with the leading enteric syndrome and signs of impaired intestinal absorption was diagnosed in 85 (77.3\%) patients; in $25(22.7 \%)$ patients an atypical form was detected, which was monosymptomatic and without a typical enteric syndrome.

Inclusion criterion: HLA typing to identify haplotypes of predisposition to celiac disease.

Centile and sigma tables evaluated indicators of physical development. WHO Anthro and AnthroPlus calculated deviations of anthropometric indicators (body weight, height and BMI Z-scor).

Statistical processing was carried out using the software package «AtteStat», «Statistica 10.0». Descriptive statistics included the calculation of the mean $(\mathrm{M}) \pm$ standard error of the mean $(\mathrm{m})$. All parametric indicators were checked for normal distribution of characteristics. To assess the intergroup differences, parametric data with a normal distribution of characteristics were evaluated using the Student t-test, and with an anomalous distribution of the characteristics, the Mann - Whitney U-test was used. The relationship assessment of nonparametric indicators was calculated by the Pearson criterion $\left(\chi^{2}\right)$. Differences between groups of patients were considered significant at $p<0.05$.

Results and Discussion. HLA-positive haplotypes of predisposition to celiac disease were detected in $108(98.2 \%)$ patients. In $87(79.1 \%)$ children, the DQ2 allele was found in $16(14.6 \%)-D Q 8$, and only in $5(4.5 \%)$ patients - DQ7. The DQ2 allele was represented 
by DQ2.5 in $26(29.9 \%)$, by the combination of DQ2.5 with DQ2.2 - in $21(24.1 \%)$, only DQ2.2 - in 7 (8.1\%) patients. The combination of DQ2 with DQ7 was detected in $25(28.7 \%)$ children, and $8(9.2 \%)$ children had a combination of DQ2 with DQ8. The DQ8 allele in 5 $(31.3 \%)$ cases was in combination with DQ8 and DQ7.

The frequency of HLA-positive haplotypes revealed by us in patients with celiac disease is comparable with the national and world data. So, in the study of Kasatkina E. N., alleles associated with celiac enteropathy were detected in $97.2 \%$ of patients with celiac disease, among whom the DQ2 allele was found in $88.6 \%$ of patients, and DQ8 molecule - in $8.6 \%$. An independent role of individual alleles of the DQ2 molecule, haplotypes DQ2.2 and DQ7 was established in the development and celiac disease [24]. In children with celiac disease in the Tomsk Region, pathological HLA alleles were detected in $77.6 \%$ of cases (DQ2 genotype in $56.6 \%$ and DQ8 in $21.0 \%$ of patients), in the Krasnodar Region HLA-positive haplotypes were detected only in $48.1 \%$ of patients [30]. In the study of Vokhmyanina N. V. (St. Petersburg), in the group of patients with celiac disease, HLA-positive haplotypes were detected in $92.4 \%$ of cases [31].

In European countries, the HLA-DQ2 haplotype is found in 90-95\% of patients and DQ8 only in 5-10\%. In most cases, the development of the celiac disease is determined by the full DQ2 molecule. Alleles of the DQ2 heterodimer determine the risk of celiac disease, both jointly and separately [28]. In a study of Mubarak A. et al. HLA haplotypes were analyzed in 155 children with celiac disease. $89.7 \%$ of patients were diagnosed with HLADQ2.5, $4.5 \%$ - HLA-DQ8, and $5.8 \%$ - HLA-DQ2.2. The authors consider the absence of these genotypes to be a decisive criterion for the exclusion of celiac disease [10].

A group of Brazilian scientists during the HLA typing of 100 children with celiac disease showed that the DQ2 allele $(51 \%-\mathrm{DQ} 2.5,22 \%-\mathrm{DQ} 2.5 / \mathrm{DQ} 2.2$ and $5 \%-$ DQ2.2) was identified in $78 \%$ of cases, the association of DQ2/DQ8 - in $13 \%$ (7\% - DQ2.5/DQ8, $6 \%$ - DQ2.2/ DQ8) and DQ8 - in $6 \%$ of patients [32].

A comparative analysis of the gender structure of our patients showed that the DQ2 allele is more common in girls - in $53(88.3 \%)$ cases, which is 1.3 times higher than in boys - in $34(68.0 \%)$ cases $(p<0.01)$. The DQ8 allele, in contrast, was 3.6 times more likely for boys - $12(24.0 \%)$ cases than for girls $-4(6.7 \%)$ cases $(p<0.01)$. The DQ7 allele was detected in $3(6.0 \%)$ boys and $2(3.3 \%)$ girls $(p>0.05)$. Among the HLA-negative patients, there was one boy and one girl.

Anamnestic data of patients with celiac disease, depending on their genetic predisposition, are shown in Table 1.

Analyzing the medical history of the disease, it was found that the onset of clinical symptoms in children occurs at different ages. In patients with the DQ2 haplotype, the average age of complaints is 2.0 times higher than in children from the DQ8 group $(p<0.01)$. It is noteworthy that the verification of celiac disease in children with the DQ2 allele occurs somewhat later than with DQ8 and DQ7 ( $>>0.05)$, which is due to the relatively large number of patients with an atypical form of the disease in this group, in which not only erased or subclinical symptoms, but also the manifestation of the disease occurs later than in the typical form.

The average latent period of celiac disease (from the onset of the first symptoms of the disease to the diagnosis) did not differ significantly in the patients of the studied groups, amounting to $2.6 \pm 0.3$ years for DQ2, 2.8 \pm 0.6 years for DQ8 and 3.1 \pm 2.2 years for DQ7 $(p>0.05)$.

Table 1

Anamnestic data of patients with celiac disease depending on the HLA allele

\begin{tabular}{|c|c|c|c|c|c|c|}
\hline \multirow{2}{*}{$\begin{array}{c}\text { Anamnestic } \\
\text { data }\end{array}$} & \multicolumn{3}{|c|}{ Haplotype HLA } & \multicolumn{3}{|c|}{$p\left(x^{2}\right)$} \\
\hline & $\begin{array}{c}\mathrm{DQ2} \\
\mathrm{n}-87\end{array}$ & $\begin{array}{c}D Q 8 \\
n-16\end{array}$ & $\begin{array}{l}\text { DQ7 } \\
n-5\end{array}$ & $p_{1}$ & $\mathrm{p}_{2}$ & $\mathrm{p}_{3}$ \\
\hline \multicolumn{7}{|c|}{ Age of complaint } \\
\hline$<1$ years & $\begin{array}{c}38 \\
(43.7 \%)\end{array}$ & $\begin{array}{c}12 \\
(75.0 \%)\end{array}$ & $\begin{array}{c}2 \\
(40.0 \%)\end{array}$ & $<0.05$ & $>0.05$ & $>0.05$ \\
\hline $1-3$ years & $\begin{array}{c}29 \\
(33.3 \%)\end{array}$ & $\begin{array}{c}3 \\
(18.8 \%)\end{array}$ & $\begin{array}{c}3 \\
(60.0 \%)\end{array}$ & $>0.05$ & $>0.05$ & $>0.05$ \\
\hline$>3$ years & $\begin{array}{c}20 \\
(23.0 \%)\end{array}$ & $(6.2 \%)$ & - & $>0.05$ & - & - \\
\hline $\begin{array}{l}\text { Middle age } \\
\text { of complaint, } \\
\text { years }\end{array}$ & $2.4 \pm 0.3$ & $1.2 \pm 0.3$ & $1.6 \pm 0.5$ & $<0.01$ & $>0.05$ & $>0.05$ \\
\hline \multicolumn{7}{|c|}{ Age of diagnosis } \\
\hline $\begin{array}{l}\text { Before } 1 \\
\text { years }\end{array}$ & $\begin{array}{c}4 \\
(4.6 \%)\end{array}$ & $\begin{array}{c}3 \\
(18.8 \%)\end{array}$ & $\begin{array}{c}2 \\
(40.0 \%)\end{array}$ & $<0.05$ & $<0.01$ & $>0.05$ \\
\hline $1-3$ years & $\begin{array}{c}33 \\
(37.9 \%)\end{array}$ & $\begin{array}{c}4 \\
(25.0 \%)\end{array}$ & $\begin{array}{c}1 \\
(20.0 \%)\end{array}$ & $>0.05$ & $>0.05$ & $>0.05$ \\
\hline $3-7$ years & $\begin{array}{c}28 \\
(32.2 \%) \\
\end{array}$ & $\begin{array}{c}8 \\
(50.0 \%) \\
\end{array}$ & $\begin{array}{c}1 \\
(20.0 \%)\end{array}$ & $>0.05$ & $>0.05$ & $>0.05$ \\
\hline $7-12$ years & $\begin{array}{c}14 \\
(16.1 \%)\end{array}$ & $\begin{array}{c}1 \\
(6.2 \%)\end{array}$ & - & $>0.05$ & - & - \\
\hline $12-18$ years & $\begin{array}{c}8 \\
(9.2 \%)\end{array}$ & - & $\begin{array}{c}1 \\
(20.0 \%)\end{array}$ & - & $>0.05$ & - \\
\hline $\begin{array}{l}\text { Middle age } \\
\text { of } \\
\text { diagnosis, } \\
\text { years }\end{array}$ & $5.1 \pm 0.5$ & $4.0 \pm 0.6$ & $4.7 \pm 2.6$ & $>0.05$ & $>0.05$ & $>0.05$ \\
\hline
\end{tabular}

Note: $\mathrm{p}_{1}$ - DQ2 vs DQ8; $\mathrm{p}_{2}-\mathrm{DQ} 2$ vs DQ7; $\mathrm{p}_{3}-\mathrm{DQ} 8$ vs DQ7.

Table 2 presents the symptoms of celiac disease in the acute period of the disease.

Symptoms of celiac disease

in children depending on the allele HLA

\begin{tabular}{|c|c|c|c|c|c|c|}
\hline \multirow{2}{*}{$\begin{array}{c}\text { Symptom } \\
\text { of celiac } \\
\text { disease }\end{array}$} & \multicolumn{3}{|c|}{ Haplotype HLA } & \multicolumn{3}{|c|}{$p\left(x^{2}\right)$} \\
\hline & $\begin{array}{c}\mathrm{DQ2} \\
\mathrm{n}-87\end{array}$ & $\begin{array}{c}\mathrm{DQ8} \\
\mathrm{n}-16\end{array}$ & $\begin{array}{l}\text { DQ7 } \\
\mathrm{n}-5 \\
\end{array}$ & $p_{1}$ & $\mathrm{p}_{2}$ & $\mathrm{p}_{3}$ \\
\hline \multicolumn{7}{|c|}{ A big symptom of $C D$} \\
\hline Diarrhea & $\begin{array}{c}50 \\
(57.5 \%)\end{array}$ & $\begin{array}{c}12 \\
(75.0 \%)\end{array}$ & $\begin{array}{c}2 \\
(40.0 \%)\end{array}$ & $>0.05$ & $>0.05$ & $>0.05$ \\
\hline $\begin{array}{l}\text { Bloating } \\
\text { of abdomen }\end{array}$ & $\begin{array}{c}46 \\
(52.9 \%)\end{array}$ & $\begin{array}{c}7 \\
(43.8 \%) \\
\end{array}$ & $\begin{array}{c}2 \\
(40.0 \%)\end{array}$ & $>0.05$ & $>0.05$ & $>0.05$ \\
\hline & $(48.3 \%)$ & $\begin{array}{c}7 \\
(43.8 \%)\end{array}$ & (40.0 \%) & $>0.05$ & $>0.05$ & $>0.05$ \\
\hline Vomiting & $\begin{array}{c}20 \\
(23.0 \%)\end{array}$ & $\begin{array}{c}2 \\
(12.5 \%)\end{array}$ & - & $>0.05$ & - & - \\
\hline & $\begin{array}{c}31 \\
(35.6 \%)\end{array}$ & $\begin{array}{c}7 \\
(43.8 \%)\end{array}$ & $\begin{array}{c}1 \\
(20.0 \%)\end{array}$ & $>0.05$ & $>0.05$ & $>0.05$ \\
\hline Irritability & $\begin{array}{c}26 \\
(29.9 \%) \\
\end{array}$ & $\begin{array}{c}5 \\
(31.3 \%) \\
\end{array}$ & $\begin{array}{c}1 \\
(20.0 \%)\end{array}$ & $>0.05$ & $>0.05$ & $>0.05$ \\
\hline & $\begin{array}{c}52 \\
(59.8 \%)\end{array}$ & $\begin{array}{c}10 \\
(62.5 \%)\end{array}$ & $\begin{array}{c}3 \\
(60.0 \%)\end{array}$ & $>0.05$ & $>0.05$ & $>0.05$ \\
\hline & $\begin{array}{c}41 \\
(47.1 \%)\end{array}$ & $\begin{array}{c}11 \\
(68.8 \%)\end{array}$ & $\begin{array}{c}1 \\
(20.0 \%)\end{array}$ & $>0.05$ & $>0.05$ & $>0.05$ \\
\hline \multicolumn{7}{|c|}{ A small symptom of CD } \\
\hline & $5(5.7 \%)$ & $1(6.3 \%)$ & - & $>0.05$ & - & - \\
\hline Caries & $1(1.1 \%)$ & $1(6.3 \%)$ & - & $>0.05$ & - & - \\
\hline Headache & $\begin{array}{c}9 \\
(10.3 \%) \\
\end{array}$ & - & - & - & - & - \\
\hline $\begin{array}{l}\text { Rest } \\
\text { slee }\end{array}$ & $\begin{array}{c}13 \\
(14.9 \%) \\
\end{array}$ & $\begin{array}{c}5 \\
(31.3 \%) \\
\end{array}$ & $\begin{array}{c}2 \\
(40.0 \%) \\
\end{array}$ & $>0.05$ & $>0.05$ & $>0.05$ \\
\hline & $\begin{array}{c}9 \\
(10.3 \%) \\
\end{array}$ & $\begin{array}{r}2 \\
(12.5 \%)\end{array}$ & - & $>0.05$ & - & - \\
\hline & $\begin{array}{c}20 \\
(23.0 \%)\end{array}$ & $\begin{array}{c}6 \\
(37.5 \%)\end{array}$ & - & $>0.05$ & - & - \\
\hline
\end{tabular}

Note: $\mathrm{p}_{1}-\mathrm{DQ} 2$ vs DQ8; $\mathrm{p}_{2}-\mathrm{DQ} 2$ vs DQ7; $\mathrm{p}_{3}-\mathrm{DQ} 8$ vs DQ7.

Table 2 
A comparative analysis of the clinical picture showed that no significant differences were depending on the presence and type of predisposition allele in children. There were also no patterns between the severity of clinical manifestations of celiac disease and combinations of DQ2 alleles.

In all groups of patients with approximately the same frequency of about $60 \%$, there was a complaint about a lack of body weight. Gastrointestinal symptoms (diarrhea, increase in the size of the abdomen, recurrent abdominal pain) in patients with the DQ2 allele occurred in $50-60 \%$ of cases. In patients with the DQ8 allele, the main complaint was unstable stool $-75.0 \%$, the second place was occupied by delay in the rate of physical development, while «minor» symptoms of the disease (skin allergic reactions, restless sleep) were somewhat more conventional.

Anthropometric characteristics of children during the verification of the diagnosis are presented in Table 3.

Table 3

Deviations of indicators of physical development in children with celiac disease depending on HLA alleles

\begin{tabular}{|l|c|c|c|c|c|c|}
\hline \multirow{2}{*}{$\begin{array}{c}\text { Z-sco- } \\
\text { re }\end{array}$} & \multicolumn{3}{|c|}{ Haplotype HLA } & \multicolumn{3}{c|}{$\mathrm{p}(\mathrm{X} 2)$} \\
\cline { 2 - 7 } & $\begin{array}{c}\mathrm{DQ2}, \\
\mathrm{n}-87\end{array}$ & $\begin{array}{c}\mathrm{DQ8}, \\
\mathrm{n}-16\end{array}$ & $\begin{array}{c}\mathrm{DQ7}, \\
\mathrm{n}-5\end{array}$ & $\mathrm{p}_{1}$ & $\mathrm{p}_{2}$ & $\mathrm{p}_{3}$ \\
\hline Weight & $-1.15 \pm 0.1$ & $-1.73 \pm 0.4$ & $-1.55 \pm 0.7$ & $<0.05$ & $>0.05$ & $>0.05$ \\
\hline Lenght & $-0.86 \pm 0.1$ & $-1.83 \pm 0.5$ & $0.03 \pm 0.6$ & $<0.005$ & $>0.05$ & $<0.05$ \\
\hline BMI & $-1.01 \pm 0.1$ & $-0.76 \pm 0.3$ & $-1.77 \pm 0.7$ & $>0.05$ & $>0.05$ & $>0.05$ \\
\hline
\end{tabular}

The analysis of anthropometric characteristics demonstrates that children with HLA-DQ8 haplotype have a more pronounced delay in physical development by weight and body length. The average Z-score of body length and body weight in patients with HLA-DQ8 is 2.1 times $(p<0.005)$ and 1.5 times $(p<0.05)$ higher than in children with HLA-DQ2. The number of children with somatogenic nanism (Z-score of body height 2 sigma deviations or more) among children with DQ8 was $37.5 \%$, which is 2.3 times higher vs. children with DQ2 allele $(p<0.05)$.

The morphological characteristics of patients with various $H L A-D Q$ variants are presented in the Figure.

The morphological structure of the jejunum mucosa in children with the DQ2 and DQ8 alleles did not differ significantly; in both cases, total villous atrophy was noted in almost $60 \%$ of the patients with celiac disease. In children with DQ7 allele, a moderate degree of atrophy was observed in $100 \%$ of cases. 2 patients with HLAnegative haplotype had Marsh $3 \mathrm{~A}$ and Marsh 3B atrophy.

E. N. Kasatkina demonstrated similar facts that features of genetic markers depending on the form of the disease and degree of jejunal mucosa damage were not detected, the author put forward a hypothesis about the role of the DQ8 molecule in the formation of atypical celiac disease [24].

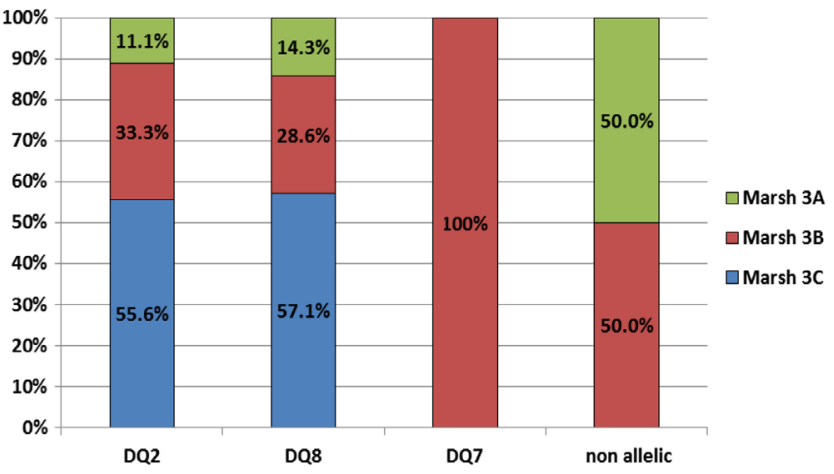

Fig. The stages of atrophy of the jejunum mucosa by Marsh - Oberhuber

When analyzing the level of specific autoantibodies in children with celiac disease depending on the HLA haplotype, it was noted that in patients with HLA-DQ2, the highest levels of anti-TTG IgA, anti-TTG IgG and EMA were observed, amounting to $121.2 \pm 8.2 \mathrm{U} / \mathrm{ml}$, 24. $1 \pm 4.7 \mathrm{U} / \mathrm{ml}$ and $759.2 \pm 95.0 \mathrm{U} / \mathrm{ml}$. In patients with DQ8 and DQ7 haplotypes, the antibody level was the following: anti-TTG IgA $-60.3 \pm 26.5 \mathrm{U} / \mathrm{ml}$ and $50.4 \pm 13.9 \mathrm{U} / \mathrm{ml}$, antiTTG IgG $-16.8 \pm 5.7 \mathrm{U} / \mathrm{ml}$ and $10.9 \pm 9.8 \mathrm{U} / \mathrm{ml}$, EMA -640.0 and $121.7 \pm 119.2 \mathrm{U} / \mathrm{ml}$, respectively.

Conclusions. The prevalence of HLA-DQ2/DQ8 haplotypes in children and adolescents with celiac disease in the Stavropol Region (southern Russia) does not differ from other regions of Russia, as well as from the structure of the genetic predisposition in populations of children and adolescents in European countries.

In the general group of patients analyzed by us, HLA haplotypes encoding the risk of celiac disease were detected in $98.2 \%$ of cases, which is consistent with Russian and world statistics. At the same time, in the southern regions of Russia, HLA-DQ8 and HLA-DQ7 haplotypes are relatively more common in children and adolescents with celiac disease.

Despite the absence of significant differences in the symptoms of the disease depending on the HLA haplotype, there are similar patterns of delayed rates of physical development, reflecting nutritional deficiencies and hormonal-metabolic disorders caused by malabsorption syndrome.

It is significant that in patients with HLA-DQ2 and HLADQ8, the structure of the mucous membrane of the small intestine atrophy stages is very close with the domination of the most severe March $3 \mathrm{C}$ stage.

The work was carried out in the framework of state tasks 2018-2020. «Identification of celiac disease among the 1st-degree relatives of patients with celiac disease» (reg. № AAAA-A19-119011890022-0).

Disclosures:

The authors declare no conflict of interest.

\section{References}

1. Caio G., Volta U., Sapone A., Leffler D. A., De Giorgio R. [et al.] Celiac disease: a comprehensive current review. BMC Med. 2019;17(1):142.

https://doi.org/10.1186/s12916-019-1380-z

2. Catassi C., Gatti S., Fasano A. The new epidemiology of celiac disease. J. Pediatr. Gastroenterol. Nutr. 2014;59(Suppl.1):S7-9

https://doi.org/10.1097/01.mpg.0000450393.23156.59
3. Klimov L. Ya., Stoyan M. V., Kuryaninova V. A., Gerasimenko E. S., Kashnikov V. S. [et al.] Diagnosis of celiac disease in groups of genetic risk: modern view on the problem. Medical News of North Caucasus. 2018;13(3):555560. https://doi.org/10.14300/mnnc.2018.13104

4. Dieli-Crimi R., Cénit M. C., Núñez C. The genetics of celiac disease: a comprehensive review of clinical implications. J. Autoimmun. 2015;64:26-41. https://doi.org/10.1016/j.jaut.2015.07.003 
5. Megiorni F., Pizzuti A. HLA-DQA1 and HLA-DQB1 in celiac disease predisposition: practical implications of the HLA molecular typing. J. Biomed. Sci. 2012;19:88. https://doi.org/10.1186/1423-0127-19-88

6. Romanos J., Wijmenga C. Predicting susceptibility to celiac disease by genetic risk profiling. Ann. Gastroenterol. Hepatol. 2010;1:1-8.

7. Diamanti A., Capriati T., Bizzarri C., Ferretti F., Ancinelli M. [et al.] Autoimmune diseases and celiac disease which came first: genotype or gluten? Expert Rev. Clin. Immunol. 2016;12(1):67-77. https://doi.org/10.1586/1744666X.2016.1095091

8. Denham J. M., Hill I. D. Celiac disease and autoimmunity: review and controversies. Curr. Allergy Asthma Rep. 2013,13(4):347-353. https://doi.org/10.1007/s11882-013-0352-1

9. Meresse B., Malamut G., Celf-Bensussan N. Celiac disease: an immunological jigsaw. Immunity. 2012;36(6):907919. https://doi.org/10.1016/j.immuni. 2012.06.006

10. Mubarak A., Spierings E., Wolters V., vas Hoogstraten I., Kneepkens C. M. [et al.] Human leukocyte antigen DQ2.2 and celiac disease. J. Pediatr. Gastroenterol. Nutr. 2013;56(4):428-430.

https://doi.org/10.1097/MPG.0b013e31827913f9

11. Fallang L. E., Bergseng E., Hotta K., Berg-Larsen A., Kim C. Y. [et al.] Differences in the risk of celiac disease associated with HLA-DQ2.5 or HLA-DQ2.2 are related to sustained gluten antigen presentation. Nat. Immunol. 2009;10(10):1096-1101. https://doi.org/10.1038/ni.1780

12. Smigoc Schweiger D., Mendez A., Kunilo Jamnik S., Bratanic N., Bratina N. [et al.] High-risk genotypes HLA-DR3DQ2/DR3-DQ2 and DR3-DQ2/DR4-DQ8 in co-occurrence of type 1 diabetes and celiac disease. Autoimmunity. 2016;49(4):240-247 https://doi.org/10.3109/08916934.2016.1164144

13. Biagi F., Bianchi P. I., Vattiato C., Marchese A., Trotta L. [et al.] Influence of HLA-DQ2 and DQ8 on severity in celiac disease. J. Clin. Gastroenterol. 2012;46(1):46-50. https://doi.org/10.1097/MCG.0b013e318221077e

14. Lundin K. E., Wijmenga C. Coeliac disease and autoimmune disease-genetic overlap and screening. Nat. Rev. Gastroenterol. Hepatol. 2015;12(9):507-515.

https://doi.org/10.1038/nrgastro.2015.136

15. Wijmenga C., Gutierrez-Achury J. Celiac disease genetics: past, present and future challenges. J. Paediatr. Gastroenterol. Nutr. 2014;59(Suppl.1):S4-7. https://doi.org/10.1097/01.mpg.0000450392.23156.10

16. Liu E., Lee H. S., Agardh D. Risk of celiac disease according to HLA haplotype and country. N. Engl. J. Med. 2014;371(11):1074. https://doi.org/10.1056/NEJMc1409252

17. Lionetti E., Castellaneta S., Francavilla R., Pulvirenti A., Tonutti E. [et al.] Introduction of gluten, HLA status, and the risk of celiac disease in children. N. Engl. J. Med. 2014;371(14):1295-1303. https://doi.org/10.1056/NEJM oa1400697

18. Romanos J., Rosén A., Kumar V., Trynka G., Franke L. [et al.] Improving coeliac disease risk prediction by testing non-HLA variants additional to HLA variants. Gut. 2014;63(3):415-422

https://doi.org/10.1136/gutjnl-2012-304110

19. Sharma A., Liu X., Hadley D., Hagopian W., Liu E. [et al.] Identification of non-HLA genes associated with celiac di- sease and country-specific differences in a large, international pediatric cohort. PLoS One. 2016:11(3):e0152476. https://doi.org/10.1371/journal.pone.0152476

20. Tye-Din J. A., Galipeau H. J., Agardh D. Celiac disease a review of current concepts in pathogenesis, prevention, and novel therapies. Front. Pediatr. 2018:6:350. https://doi.org/10.3389/fped.2018.00350

21. Husby S., Murray J. A., Katzka D. A. AGA clinical practice update on diagnosis and monitoring of celiac disease changing utility of serology and histologic measures: expert review. Gastroenterology. 2019;156(4):885-889. https://doi.org/10.1053/j.gastro.2018.12.010

22. Parfenov A I. Bykova S. V., Sabel'nikova E. A., Maev I. V., Baranov A. A. [et al.] All-Russian Consensus on Diagnosis and Treatment of Celiac Disease in Children and Adults. Ter. Arkh. 2017;89(3):94-107.

https://doi.org/10.17116/ terarkh201789394-107

23. Kelly C. P., Bai J. C., Lui E., Leffler D. A. Advances in diagnosis and management of celiac disease. Gastroenterology. 2015;148(6):1175-1186.

https://doi.org/10.1053/j.gastro.2015.01.044

24. Kasatkina E. N. Kliniko-laboratornaya kharakteristika razlichnykh form tseliakii $v$ zavisimosti ot geneticheskikh markerov zabolevaniya. Avtoreferat diss. ... k.m.n. M. 2012.

25. Kasatkina E. N., Dmitrieva Yu. A., Roslavtseva E. A., Borovic T. E., Zakharova I. N. Distribution of HLA-DR-DQ genotypes in Russian children with coeliac disease. J. Pediatr Gastroenterol. Nutr. 2018;66(suppl.1):S151-151.

26. Savvateeva L. V., Erdes S. I., Antishin A. S., Zamyatnin A. A. Jr. Current Paediatric Coeliac Disease Screening Strategies and Relevance of Questionnaire Survey. Int. Arch. Allergy Immunol. 2018;27:1-11. https://doi.org/10.1159/000491496

27. Troncone R., Discepolo V. Celiac disease and autoimmunity. J. Paediatr. Gastroenterol. Nutr. 2014;59(Suppl.1):S9-11. https://doi.org/10.1097/01. mpg.0000450394.30780.ea

28. Zakharova I. N., Borovik T. E., Roslavtseva E. A., Kasatkina E. N., Dmitrieva Yu. A. Genetic markers of celiac disease: modern concern. Pediatrician (St. Petersburg). 2014;5(2):19-24.

29. Klimov L. Ya., Stoyan M. V., Kur'yaninova V. A., Kashnikov V. S., Eremeeva O. I. [et al.] The dynamics of the prevalence and a clinical-anthropometric characteristic of patients with coeliac disease in the Stavropol region: a retrospective analysis over a 20-year period. Vopr. det. dietol. (Pediatric Nutrition). 2018;16(3): $5-14$.

https://doi.org/10.20953/1727-5784-2018-3-5-14

30. Yankina G. N. Kliniko-geneticheskoe i immuno-morfologicheskie aspekty celiakii u detej. Strategiya reabilitacii. Avtoreferat diss. ... d.m.n. Tomsk, 2014

31. Vohmyanina N. V. Laboratornaya diagnostika celiakii: principy i algoritmy. Avtoreferat diss. ... d.m.n. SPb., 2014.

32. Selleski N., Almeida L. M., Almeida F. C., Pratesi C. B. Nóbrega Y. K. M. [et al.] Prevalence of celiac disease predisposing genotypes, including HLA-DQ2.2 variant, in Brasilian children. Arq. Gastroenterol. 2018;55(1):82-85. https://doi.org/10.1590/S0004-2803.201800000-16

\section{About autors:}

Klimov Leonid Yakovlevich, PhD, Associate Professor, Head of the Department of faculty of pediatrics; tel.: +79289630261; e-mail: klimov_leo@mail.ru

Stoyan Marina Valerievna, PhD, Assistant, Gastroenterologist;

tel.: +79282447990; e-mail: marina-stoyan@mail.ru

Kuryaninova Victoria Aleksandrovna, PhD, Associate Professor;

Head of the Department of gastroenterology; tel.: +79282938069; e-mail: vichkak@mail.ru

Zakharova Irina Nicolaevna, MD, PhD, Professor; tel.: +79166020368; e-mail: zakharova-rmapo@yandex.ru

Atanesyan Roza Arturovna, PhD, Assistant of the Department of endocrinology, pediatric endocrinology and diabetology;

tel.: +79283770998; e-mail: rozaatanesyan@rambler.ru

Zavyalova Ekaterina Valerievna, postgratuate student, Gastroenterologist;

tel.: +79034163334; e-mail: katy7724@yandex.ru

Kochneva Lyubov Dmitrievna, clinical resident; tel.: +79054420367; e-mail: kochneva.lyubov.96@mail.ru

Ivanova Alla Victorovna, postgratuate student; tel.: +79298380408; e-mail: ivanova1907@list.ru 